\title{
Employer Brand Role in HR Recruitment and Selection
}

\author{
Olga Starineca, University of Latvia
}

\begin{abstract}
This paper's research focuses on employer brand (EB) development as a solution for public sector organizations to attract the young specialists of Latvia.

The author uses monographic research method, selection, comparison, induction and statistical data interpretation to explore the situation and potential outcomes of the proposed approach to Human Resource Recruitment and Selection.

The research results show that public organizations in Latvia still need to improve their positioning on labour market and work harder on their EB.
\end{abstract}

Keywords - Employer brand, Human Resources recruitment and selection.

\section{INTRODUCTION}

There are a lot of risks concerning the employment of new, especially young specialists, in public organizations. Latvian young specialists admit that public organizations usually provide stable but not dynamic work (Starineca, 2014). Generation Y specialists prefer to find both comfortable and interesting work. Young urban specialists with higher education rather work, because they want to, not because they have to. (Matthewman, 2011) Therefore, young specialists that could work for public sector organizations usually are more attracted by private organizations with needs and values adaptive to the modern society.

It is possible to solve this issue, and it needs to be solved bearing in mind demographic issues in Europe. One of these issues is unemployment in European countries. It is still high. In August 2014 seasonally adjusted unemployment rates in 28 European Union (EU) countries was 10.1\% (Eurostat, 2014a). Another issue is ageing European society. "The share of the population aged 65 years and over is increasing in every EU Member State" (Eurostat, 2014), for the period from 2002 till 2012 the increase was $1.9 \%$ in 28 EU countries. In the Baltic States this increase was between $2 \%$ and $4 \%$. The share of population under 15 years in $28 \mathrm{EU}$ countries has decreased by $1.2 \%$ for the same period. (Eurostat, 2014) This causes a lot of other issues connected to the employability, taxation policy, etc. Also young educated labour force emigration is an issue. Those, who are not attracted by the work supply on local labour market tend to find the most suitable for them place of employment abroad, especially, if they are young, ambitious and single (Fratesi, 2014). In many cases the destination of these job seekers are private organizations.

In a situation, where public organizations are forced to compete for specialists with private organizations, one of the possible solutions could be working towards the improvement of Employer Brand (EB) of public organizations. Employer
Branding (EB) as a tool of attraction of job applicants has a tight connection to Human Resources recruitment and selection (HRRS) activities. A human resources department is dealing with the new employees' recruitment and selection, as well as executives of an organization (Dessler, 2010). All employees of the organization are creating and developing EB. Besides, some studies have already proved that EB constraints applicants' job seeking behaviour (Gomes \& Neves, 2010). Therefore, the investment in EB is an example of strategic HR planning.

EB involves work with organization culture, relationship development between the organization and its stakeholders and such activities as definition and implementation of organizational values, mission, vision and goals. Therefore, the author has researched characteristic components of several Latvian public (mainly administrative) organizations to evaluate current situation of the EB external expression of organisations. The EB external expression is looked upon from the point of view of job seekers, who analyze and choose their potential employers by using publicly available sources of information.

The aim of the research was to outline the EB importance, connection, effect and expression within HRRS based on the case of Latvia. The objective of the paper was to compare the EB external expression of socially responsible (SR) and other public sector organizations in Latvia. The tasks of the research were: 1) to analyze statistical data concerning the employment among young specialists in Latvia; 2) to outline young specialists' typical characteristics; 3) to overview employees' peculiarities in public sector organizations; 4) to perform EB literature analysis; 5) to compare the EB external expression of SR and other public sector organizations in Latvia according to the elements of EB external expression; 6) to make conclusions.

The author used monographic research method, selection, comparison, induction and statistical data interpretation to explore the situation and potential outcomes of the proposed approach to HRRS.

\section{PUBLIC ORGANIZATIONS AND EMPLOYMENT OF YOUNG SPECIALISTS IN LATVIA}

Based on previous studies the author can conclude that Latvian labour market requires highly qualified specialists with work experience. Public organizations particularly require experienced specialists. (Voronchuk \& Starineca, 2014) Young specialists under the age of 24 usually have poor work experience or do not have it at all; therefore it is hard for them to enter labour market. However, private sector 
organizations provide more working places in general as well as traineeship places. (Central Statistical Bureau of Latvia, 2014)

The situation is complex and median and the state statistical data wreak havoc telling that youth unemployment rate is high in Latvia. However, statistical data also show that the second popular reason why economically inactive Latvian inhabitants are not looking for a job is "studies" $(25.0 \%$ out of all other reasons in 2013). Statistical data that reflect unemployment rates usually provide information on youth aged between 15 and 24. Latvia is in the transition to knowledge economy, where people are striving to get higher education. In 2013 $83.7 \%$ of Latvian inhabitants with higher education were economically active which is by $11.8 \%$ more than the next group of inhabitants in the rating - inhabitants with vocational education or vocational secondary education. During the last three years there has been a tendency for the number of people with higher education who are looking for a job in Latvia to increase (LR Centrālā statistikas pārvalde, 2014a). Therefore people who are 15, 16 and even 17 year old rather study than work. In the beginning of 2014 there were 51453 young Latvian inhabitants in the age from 15 to 17 that is $22.7 \%$ out of all Latvian inhabitants in the age range from 15 to 24 years (Central Statistical Bureau of Latvia, 2014a). 25.8\% of economically inactive inhabitants are pupils or students. Besides, people of this age may not work as much as other mature young people in the set age group of 15-24 years old under the law (LR Centrālā statistikas pārvalde, 2014). The author reflects that it is not correct to consider this part of Latvian inhabitants bearing in mind that youth unemployment as the result of analyzed data is not precise enough.

Based on previous studies the author also can conclude that public organizations mostly are searching specialists with higher education (bachelor or master degree) for the vacant positions (Voronchuk \& Starineca, 2014).

The structure of the public sector provides various jobs in central and local government (nonfinancial public sector). (Voronchuk \& Starineca, 2014) The author in her analysis focuses only on administrative jobs in public organizations. In 2013 in Latvia $7.41 \%$ of the total amount of employed people worked in administrative jobs in public organizations. (Central Statistical Bureau of Latvia, 2014)

Latvian society is ageing, and the staff of public organizations is ageing as well. For example, $59.23 \%$ of employees of the Central Statistical Bureau of Latvia in 2013 were in the age of 45 or older (LR Centrālā statistikas pārvalde, 2014b). According to the author's survey in summer 2014 the average age of employees in State Revenue Service was 43 years, in State Probation Service - 41 year, in State Forensic Science Bureau - 40 years, in State Centre for Forensic Medical Examination of Latvia - 52 years. Therefore there is a risk that after 10-15 years there will be no specialists to replace them. One of the possible solutions could be to attract young specialists and to work on their retention. One tool that can help in this case is organizations' work on their Employer Brand.

Another aspect is the existing peculiarities of young specialists. Currently young specialists with higher education are generation $\mathrm{Y}$ representatives (sometimes also called Echo Boomers, Generation Next, Millennials, Boomlets, I Generation, Net Generation, Netizens, Generation WHY). According to the different sources they were born from 1978 2000 (Sheahan, 2006; Osborne, 2010; Matthewman, 2011). They have specific characteristics as potential employees. They could be characterized as ambitious citizens of the world who are active technology users (Ārste-Avotina \& Liegis, 2013). They are searching for a job using Internet resources, thus written and visual information is important for them. They are attracted by active work environment and professional development opportunities in the work place (Starineca, 2014). They go with new, trendy ideas, hence they are mostly attracted by big brand names rather than the real content. From the employers' perspective it is important to give them what they want in order to be able to compete for this type of Human Resources. Thus the Employer Branding is a useful approach for Latvian public organizations under many circumstances.

\section{THEORETICAL FRAMEWORK OF EMPLOYER BRANDING}

Employer Brand is a tool for employers that can help carry out various HR processes especially those connected with external organizational environment interaction. Jain and Pal (2012) outline several EB benefits. Employer Branding can help to achieve the increase in organization's productivity, profitability, employee retention, and employer attractiveness as well as the reduction of recruitment costs and period of time from hiring a new specialist till receiving real value from his work (Starineca \& Voronchuk, 2014). Also EB can enhance employee commitment towards organizational goals and contribute to minimization of loss of talented employees, as well as improve employee relations (Jain and Pal, 2012). All these benefits make organizations to think of the positive effect of some essential activities regarding their EB in general. Therefore organizations may be interested in EB implementation.

The literature review helped to understand the crucial steps of employer branding process. Five different explanations of EB were compared and analyzed. Based on this analysis the general scheme of EB was developed using a linguistic tool Word Count which automatically showed the most frequently used words in the observed five pieces of texts. The main words that were used most frequently were: "employment", "employer", "identity", "directed", "external" and "employees" (Lievens, 2007; Jain \& Pal, 2012; Bondarouk et al., 2012; Pahor \& Franca, 2012; Kudret, 2014).

It was possible to conclude that EB is "an identity of employer that is directed to the external and internal stakeholders and speaks about employment image by several criteria provided by the employer" (Voronchuk \& Starineca, 2014a).

Five different approaches to the interpretation of EB theoretical content were analyzed (Table I):

- $\quad$ Three-step processes of EB (Lievens, 2007);

- $\quad$ EB components (Jain \& Pal, 2012);

- $\quad$ EB elements/EB mix dimensions (Bondarouk, Ruël, \& Weekhout, 2012);

- $\quad$ EB main characteristics (Pahor \& Franca, 2012); 
- $\quad$ EB mix dimensions (Kudret, 2014).

The main components of EB were outlined: culture and environment of the organization, job content, features and benefits that employees can receive working for the employer (Starineca \& Voronchuk, 2014).

It is possible to split all the mentioned components into three main blocs:

- Employees and culture of an organization;

- External reputation of an employer;

- Work environment and employment circumstantial.

The author summarized all the possible elements of EB and compiled a list of them (Voronchuk \& Starineca, 2014a).

- Organizational characteristics:

- What kind of organization is it?

- What does organization offer for employees?

- What are the organizing processes (vision, mission, goals)?

- People:

- What kind of employees it employs?

-What is expected of employees?

- Culture:

- Internal communication;

○ Rewards and recognition;
○ Learning and development;

- Service support;

- Measurement system;

- Current culture and ethics in the organization.

- Job characteristics:

○ Job opportunities;

○ Job learning opportunities;

- Key functions and specific characteristics;

- Introduction program.

- Remuneration and advancement:

- Advancement opportunities;

- Career programs;

○ Benefits and compensation system.

- Employment:

○ Working environment;

○ Recruitment and induction;

- Team management;

- Performance appraisal.

- Employer reputation:

- Past achievements;

- Social activities, sponsorship etc.;

- Ratings of products and services s.

TABLE I

AMOUNT OF ORGANIZATIONS ACCORDING TO EXTERNAL EXPRESSION OF THE OBSERVED EB COMPONENTS, \%

\begin{tabular}{|c|c|c|c|c|}
\hline Lievens (2007) & Jain and Pal (2012) & Bondarouk et al. (2012) & Pahor and Franca (2012) & Kudret (2014) \\
\hline $\begin{array}{c}\text { Three-step } \\
\text { processes of EB }\end{array}$ & EB components & EB elements/EB mix dimensions & EB main characteristics & EB mix dimensions \\
\hline $\begin{array}{l}\text { 3.2. EB transition to } \\
\text { the organizational } \\
\text { culture }\end{array}$ & $\begin{array}{l}\text { 1. Culture and Environment } \\
\text { Work practice, value system, } \\
\text { behaviour and attitude of the } \\
\text { people working in the } \\
\text { organization }\end{array}$ & $\begin{array}{c}\text { 1. People and culture } \\
\text { What kind of employees are } \\
\text { employed? What is expected of } \\
\text { employees? Employment conditions } \\
\text { and treatment of employees; } \\
\text { Current culture and ethics in the } \\
\text { organization. }\end{array}$ & $\begin{array}{l}\text { 1. Good leadership and job- } \\
\text { life balance }\end{array}$ & $\begin{array}{c}\text { 1. Culture } \\
\text { Internal communication, } \\
\text { rewards and recognition, } \\
\text { learning and development, } \\
\text { service support, } \\
\text { measurement system }\end{array}$ \\
\hline $\begin{array}{l}\text { 1. The value } \\
\text { proposition of an EB } \\
\text { development } \\
\text { 2. The external } \\
\text { marketing of EB }\end{array}$ & $\begin{array}{l}\text { 2. Employment Experience } \\
\text { Tangibles (salary and } \\
\text { benefits); Intangibles } \\
\text { (company's culture and } \\
\text { values, opportunities for } \\
\text { learning and career } \\
\text { progression, reward and } \\
\text { recognition and management } \\
\text { style) }\end{array}$ & $\begin{array}{l}\text { 2. Organizational characteristics } \\
\text { What kind of organization it is and } \\
\text { what it offers? How is the } \\
\text { organization offered? } \\
\text { Organizational processes (vision, } \\
\text { mission, future goals) } \\
\text { 3. Employer's reputation } \\
\text { Past achievements, social activities, } \\
\text { sponsorship etc., ratings of } \\
\text { products and services ratings }\end{array}$ & $\begin{array}{l}\text { 2. Reputation of company } \\
\text { and its products and/or } \\
\text { services }\end{array}$ & $\begin{array}{c}\text { 2. Purpose } \\
\text { Senior management; } \\
\text { values/corporate social } \\
\text { responsibility }(C S R), \\
\text { external marketing }\end{array}$ \\
\hline $\begin{array}{l}\text { 3.1. The internal } \\
\text { marketing of EB }\end{array}$ & $\begin{array}{c}\text { 3. Integrity } \\
\text { 4. Employment Package } \\
\text { Financial compensation, job } \\
\text { roles and responsibilities, } \\
\text { work environment, career } \\
\text { development plan }\end{array}$ & $\begin{array}{c}\text { 4. Job characteristics } \\
\text { Job opportunities, job learning } \\
\text { opportunities, key functions and } \\
\text { specific characteristics, } \\
\text { introduction program } \\
\text { 5. Remuneration and advancement } \\
\text { Advancement opportunities, career } \\
\text { programs, benefits and } \\
\text { compensation system }\end{array}$ & $\begin{array}{l}\text { 3. Possibilities for personal } \\
\text { development } \\
\text { 4. Security of employment }\end{array}$ & $\begin{array}{c}\text { 3. Employment } \\
\text { Working environment, } \\
\text { recruitment and induction, } \\
\text { team management, } \\
\text { performance appraisal }\end{array}$ \\
\hline
\end{tabular}

Source: Starineca \& Voronchuk, 2014

The aspects that can be easily evaluated by external stakeholders, e.g. job seekers - potential employees of an organization, are those that can be assessed externally. Mainly they could be organizational characteristics. Nowadays one of the easiest ways to inform external stakeholders about the organizational characteristics is the WEB page of an organization. Therefore the author evaluated the components of organizational characteristics of the set public sector organizations. 


\section{METHODOLOGY OF THE STUDY}

To analyze the external expression of public organizations' $\mathrm{EB}$, the author selected 30 public administrative organizations of Latvia. The selection was based on the results of previous research (organizations were chosen from the list of public organizations which were searching for new employees for administrative positions and on July 3, 2014 published their job advertisements on www.cv.lv). All job advertisements of the public organizations were published on the portal (job search engine $w w w . c v . l v$, it is easy to retrieve the job advertisements from this portal). Some of job advertisements were from municipal and some from state organizations. The filter applied to the appropriate job advertisement selection is "State and public administration".

The results of this analysis were compared with the same analysis of ten socially responsible public organizations that were included in the Latvian Sustainability Index in 2014. SR organizations were chosen because the organizational process is one of the evaluation sub-criterion of SI. Organizations that were included into the SI rating were a priori the best examples of organizational identity expression. (Sustainability Index, 2014) All observed organizations represented nonfinancial public sector (Voronchuk \& Starineca, 2014).

EB external expression analysis was mainly conducted by collecting information on organizations' values, their defined vision, mission and goals of organizations that was available on the organizations' web sites. Nowadays for the job seekers, especially urban young job seekers, the web page of an organization is one of the most attainable and popular information resources about the organization. Therefore, it was reasonable to choose exactly this source to explore. Organizational processes (vision, mission, goals) are part of the organizational characteristics, whereas organizational characteristics are one of the five EB mix dimensions (Bondarouk et al., 2012).
The author reviewed the whole content of web pages to find any information that discloses the organization's definition, its offers to employees, organizational process (if at least one of the components exists), vision, mission, goals, operational principles, Code of Ethics and its full text.

The study is subject to several limitations. Only Latvian public organizations are examined for the exact short period defined by the set criteria. This decision was guided by simplicity of filter and comparison of Latvian organizations, as there is a Sustainability Index rating in Latvia.

According to the requested data from the State Employment Agency, there were around 418 vacancies in Latvian public organizations for the first ten month in 2014, however only 30 and only administrative organizations were observed.

There was only one source of information purposely used and only one EB element was purposely chosen for the observation.

\section{RESULTS OF THE STUDY}

After analyzing EB approaches and definitions, the author summarized the most frequently used words. As a result, EB could be characterized mainly by: employment, employer, identity, directed, external, employees, branding, culture, and environment. So, the essence of the Employer Brand is mainly the external expression of internal culture and environment of an organization from the employment perspective.

The examined organizations were public sector organizations: administrative (all 30 from the range), one administrative SR organization, one SR higher education institution, and eight state-owned or municipal enterprises. All observed organizations had web pages.

After the examination of public organizations the author drew the results by the elements of their organizational characteristics as well as by other additional evaluation criteria, such as operational principles statement and publication of Code of Ethics (Table II).

TABLE II

AMOUNT OF ORGANIZATIONS ACCORDING TO EXTERNAL EXPRESSION OF THE OBSERVED EB COMPONENTS, \%

\begin{tabular}{|c|c|c|c|c|c|c|c|c|}
\hline $\begin{array}{l}\text { Elements of } \\
\text { organizational } \\
\text { characteristics and } \\
\text { other evaluation } \\
\text { criteria }\end{array}$ & $\begin{array}{c}\text { Definition of } \\
\text { what kind of } \\
\text { organization it } \\
\text { is }\end{array}$ & $\begin{array}{l}\text { Definition of what } \\
\text { organization } \\
\text { offers for } \\
\text { employees }\end{array}$ & $\begin{array}{c}\text { Definition of } \\
\text { organizational } \\
\text { processes }\end{array}$ & $\begin{array}{l}\text { Definition } \\
\text { of vision }\end{array}$ & $\begin{array}{l}\text { Definition } \\
\text { of mission }\end{array}$ & $\begin{array}{l}\text { Definition } \\
\text { of goals }\end{array}$ & $\begin{array}{l}\text { Definition } \\
\text { of } \\
\text { operational } \\
\text { principles }\end{array}$ & $\begin{array}{l}\text { Publication } \\
\text { of the Code } \\
\text { of Ethics }\end{array}$ \\
\hline $\begin{array}{l}\text { Out of } 30 \text { public } \\
\text { organizations }\end{array}$ & $93.33 \%$ & $60.00 \%$ & $30.00 \%$ & $6.67 \%$ & $10.00 \%$ & $23.33 \%$ & $10.00 \%$ & $26.67 \%$ \\
\hline $\begin{array}{l}\text { Out of } 10 \mathrm{SR} \text { public } \\
\text { organizations }\end{array}$ & $100.00 \%$ & $50.00 \%$ & $90.00 \%$ & $60.00 \%$ & $70.00 \%$ & $50.00 \%$ & $20.00 \%$ & $20.00 \%$ \\
\hline
\end{tabular}

Sources: Latvenergo (2014); Latvijas loto (2000-2002); Rīgas siltums (2014); Daugavpils siltumtīkli (2013); Ventspils reiss (2014); Riga Technical University (2013); Road Traffic Safety Directorate of the Republic of Latvia (2011); Riga Internationl Airport (2009); Latvijas dzelzcelš (2006); Latvijas autocelu uzturētājs (2007); Uzñèmumu registrs (2014); Valsts kase (2007-2014); Latvijas Republikas Finanšu Ministrija (2012); VARAM (2006); VRAA (2014); Zemkopības ministrija (2011); Tukuma novada sociālais dienests (2014); Health Inspectorate of Latvia (2011); Centrālā finanšu un līgumu agentūra (2011); VSAA (2014); Bauskas novada pašvaldība (2014); Vides pārraudzības valsts birojs (2009); Zemkopības ministrija (2011); Valsts tehniskās uzraudzības aǵgentūra (2005-2013); Latvijas Republikas Ärlietu ministrija (2014);Latvijas Republikas Ekonomikas ministrija (2010); VID (2005); VAAD (2009), (2014); NVA (2005); NVD (2014); SIVA (2006-2012); LR Centrālā statistikas pārvalde (2014c); Jaunatnes starptautisko programmu aǵgentūra (2014); Datu valsts inspekcija (2014); VZD (2014); Labklājības ministrija (2008-2012); Latvijas Republikas Tieslietu ministrija (2014); PTAC (2009); Lauku atbalsta dienests (2010); Valsts dzelzceḷa tehniskā inspekcija (2007).

There were two public organizations out of 30 that did not provide clear description of the organization on their web pages. Public administrative organizations (60.00\%) employees on their web pages, mainly in the vacancies section, describing offers for a potential employee. $50.00 \%$ of highlighted information on what organization offers for their observed SR organizations provided the same information. 
SR organizations publish their defined mission in more cases $(70.00 \%)$ than other analyzed public organizations $(10.00 \%)$. The same situation was with other elements of organizational processes, e.g. $23.33 \%$ of the analyzed public organizations and $50.00 \%$ of SR public organizations publish their goals.

$26.67 \%$ of the observed public organizations publish their code of ethics that is by $6.67 \%$ more than SR public organizations do. Operational principles are published on web pages of $20.00 \%$ of SR public organizations that is by $10 \%$ more than in the case of other public organizations analyzed.

Additionally the author checked the values of organizations. Socially Responsible public sector organizations defined their values more frequently ( $40.00 \%$ of the SR organizations) than other public organizations from the range $(10.00 \%)$. Only one out of three public administrative organizations from the sample defined its employees as a value, and only two out of four SR organizations defined their employees as a value.

\section{DISCUSSION}

It is a fact that Latvian society is ageing. The number of vacancies for people with higher education is increasing as well as the number of people with higher education in Latvia. Labour market provides a choice of different vacancies in the common fields, therefore not only organizations are selecting future employees, but also job seekers are selecting their future employers. Even in terms of high unemployment rate job seekers have a possibility to choose some extra features of the employing organizations which are most suitable for them, especially if these job seekers are young specialists (currently up to 35 year old). This is where employers' monopolistic competition starts.

The objective of the paper is to compare EB external expression of SR and other public sector organizations in Latvia. The result shows that socially responsible organizations usually care about the external manifestation of the employer brand attributes more than other public organizations. It is important to outline that the form of the public organization is important. Naturally, public enterprises are more interested to compete with private sector enterprises; therefore, they are more active in communication with external stakeholders including job seekers and potential employees as well as in caring about their reputation and services, treating carefully their current employees.

Further research is needed to analyze the expression of other EB components as some of their elements can be also expressed via the internet resources or by word-of-mouth as one of the most effective communication approach.

\section{CONCLUSION}

SR organizations are more open and adapted to employer branding. Most probably this result reflects the passive approach of Latvian public administrative organizations to HR recruitment and selection, work with their stakeholders (current and potential employees) as the biggest part among the examined SR organizations are state-owned or municipal enterprises.

The research results show that public organizations in Latvia still need to improve their positioning on labour market and work harder on their EB. Even considered SR public organizations have weak external expression of their EB that cannot contribute to successful results of HRRS. However, SR public organizations generally are more open about publishing information that characterizes them as employers and influences their employer brand creation/development.

The results of the study characterize the content of web pages of Latvian public sector organizations that is important for the external expression of the employer brand elements. Job seekers, who check potential employers' web pages, simply cannot find information that shows the organization as an employer. It means that public organizations of Latvia are not that oriented on the communication via internet resources with one of their important stakeholder - potential employees.

Nowadays young specialists are likely the most active internet resources users, therefore public organizations need to pay distinctive attention to information that they are publishing particularly the one that can affect the attraction of new candidates to the vacant positions.

The suggestion for the organizations would be to devote more attention to the content of the organizational web pages. Information that can be published has to be published on the web page and be easily reached to attract job seeker and to represent the organization as an employer. The main focus needs to be on organization's definition, its offers to the employees, organizational process (if at least one of the components exists), vision, mission, goals, operational principles, Code of Ethics and its full text. If there is no such information to publish, it can be an additional point to think on. Most probably, the organization needs to develop its plan to include there all cultural aspects of the organization's management and activity as well as such strategic elements as vision and goals.

\section{REFERENCES}

Ārste-Avotina, A. \& Lieǵis V. (2013). Jaunā Y paaudze. Forbes Latvia. 11, 82-83. Bauskas novada pašvaldība (2014). Retrieved Jul. 03, 2014, from http://www.bauska.lv/

Bondarouk, T., Ruël, H., \& Weekhout, W. (2012). Employer Branding and its Effect on Organizational Attractiveness via the World Wide Web: Results of quantitative and qualitative studies combined. The 4th International e-HRM Conference "Innovation, Creativity and eHRM”, March 28-29, Nottingham, UK.

Central Statistical Bureau of Latvia (2014). Occupied Posts by Kind of Economic Activity on Average per Year by Kind of activity. Retrieved Apr. 01, 2014, from http://data.csb.gov.lv/Table.aspx?layout=tableViewLayout1\&px_tabl eid=jvs0010g.px\&px_path=Sociala_Ikgad\%C4\%93jie\%20statistika s\%20dati_Aiz\%C5\%86emt $\%$ C4\%81s\%20un\%20br\%C4\%ABvas\% 20darbvietas\%20apmaks\%C4\%81tais\%20darba\%20laiks\&px_langua ge $=$ en $\& p x \_d b=$ Sociala\&rxid=992a0682-2c7d-4148-b242$7 \mathrm{~b} 48 \mathrm{ff} 9 \mathrm{fe} 0 \mathrm{c} 2$

Central Statistical Bureau of Latvia (2014a). Collection of Statistical Data. Demography 2014. Retrieved Oct. 20, 2014, from http://www.csb.gov.lv/sites/default/files/publikacijas/nr_11_demogra fija_2014_14_00_lv_en.pdf

Centrālā finanšu un līgumu aǵentūra (2011). Retrieved Jul. 03, 2014, from http://www.cfla.gov.lv/lv/

Datu valsts inspekcija (2014). Retrieved Jul. 03, 2014, from http://www.dvi.gov.lv/lv/

Daugavpils siltumtīkli (2013). Retrieved Jun. 15, 2014, from http://www.dsiltumtikli.lv/

Dessler, G. (2010). Human Resources Management. 12th ed. New Jersey: Pearson Education, Inc. 
Eurostat (2014). Retrieved Dec. 14, 2014, from http://ec.europa.eu/eurostat/statisticsexplained/index.php/Population_structure_and_ageing

Eurostat (2014a). Retrieved Nov. 11, 2014, from http://ec.europa.eu/eurostat/statisticsexplained/index.php/Unemployment_statistics

Fratesi, U. (2014). Editorial: The Mobility of High-Skilled Workers - Causes and Consequences. Regional Studies, 48 (10), 1587-1591. http://dx.doi.org/10.1080/00343404.2014.955689

Gomes, D. R., \& Neves, J. (2010). Employer Branding Constrains Applicants' Job Seeking Behaviour?. Revista De Psicologia Del Trabajo Y De Las Organizaciones, $26 \quad$ (3), 223-234. http://dx.doi.org/10.5093/tr2010v26n3a6

Health Inspectorate of Latvia (2011). Retrieved Jul. 03, 2014, from http://www.vi.gov.lv/

Jain, V., \& Pal, R. (2012). Importance of Employer Branding in Business UpGradation. International Journal of Research in IT \& Management, 2(11), 68-75. Retrieved from Euro Asia Research and Development Association. Retrieved from http://www.euroasiapub.org

Jaunatnes starptautisko programmu aǵentūra (2014). (2014). Retrieved Jul. 03 , 2014, from http://jaunatne.gov.lv/

Kudret, S. (2014). Branding the Employment Experience. The ESCP Europe 9th International Marketing Trends Conference, January 24-25, Venice, Italy.

Labklājības ministrija (2008-2012). Retrieved Jul. 03, 2014, from http://www.lm.gov.lv/

Latvenergo (2014). Retrieved Jun. 15, 2014, from https://www.latvenergo.lv/

Latvijas autoceḷu uzturētājs (2007). Retrieved Jun. 15, 2014, from http://www.lau.lv/pub/

Latvijas dzelzceḷš (2006). Retrieved Jun. 15, 2014, from http://www.ldz.lv/

Latvijas loto (2000-2002). Retrieved Jun. 15, 2014, from http://www.latloto.lv/

Latvijas Republikas Ārlietu ministrija (2014). Retrieved Jul. 03, 2014, from http://www.mfa.gov.lv/lv/Jaunumi/zinas/

Latvijas Republikas Ekonomikas ministrija (2010). Retrieved Jul. 03, 2014, from http://www.em.gov.lv/

Latvijas Republikas Finanšu Ministrija (2012). Retrieved Jul. 03, 2014, from http://www.fm.gov.lv/

Latvijas Republikas Tieslietu ministrija (2014). Retrieved Jul. 03, 2014, from http://www.tm.gov.lv/

Lauku atbalsta dienests (2010). Retrieved Jul. 03, 2014, from http://www.lad.gov.lv/lv/

Lievens, F. (2007). Employer branding in the Belgian Army: The importance of instrumental and symbolic beliefs for potential applicants, actual applicants, and military employees. Human Resource Management (special issue: Human Resource Management and Leadership Lessons from the Military), 46(1), 51-69. http://dx.doi.org/10.1002/hrm.20145

LR Centrālā statistikas pārvalde (2014a). Darba mēklētāji pēc izglìtîbas līmeña un dzimuma pa ceturkšnem. Retrieved Apr. 01, 2014, from http://data.csb.gov.lv/Table.aspx?layout=tableViewLayout1\&px_tabl eid=NB0200c.px\&px_path=Sociala \%C4\%AAstermi $\%$ C5\%86a\%2 0statistikas\%20dati_Nodarbin\%C $4 \% 81$ \% $\% 4 \% \mathrm{ABba} \% 20 \mathrm{un} \% 20 \mathrm{bez}$ darbs\&px_language=lv\&px_db=Sociala\&rxid=09 cbdccf-2334-4466bdf7-0051bad1decd

LR Centrālā statistikas pārvalde (2014b). Personāls. Retrieved Oct. 23, 2014, from http://www.csb.gov.lv/par-mums/personals-27823.html

LR Centrālā statistikas pārvalde (2014c). Retrieved Jul. 03, 2014, from http://www.csb.gov.lv/

LR Centrālā statistikas pārvalde, (2014). Darbaspēka Apsekojuma galvenie rādītāji 2001.-2013. gadā. Retrieved Oct. 20, 2014, from http://www.csb.gov.lv/sites/default/files/nr_17_darbaspeka_apsekoju ma_galvenie_raditaji_latvija_2001-2013_gada_2014_00_lv.pdf

Matthewman, J. (2001). The Rise of the Global Nomad. London/Philadelphia: Kogan Page.

NVA (2005). Retrieved Jul. 03, 2014, from http://www.nva.gov.lv/

NVD (2014). Retrieved Jul. 03, 2014, from http://www.vmnvd.gov.lv/

Osborne, S.C. (2010). Home Staging that Works: Sell Your Home in Less Time for More Money. New York: AMACOM.

Pahor, M., \& Franca, V. (2012). The Strength of the Employer Brand: Influences and Implications for Recruiting. Journal of Marketing and Management 3 (1), 78-122. Retrieved from Global Strategic Management Incorporated, USA, Journals. Retrieved from http://www.gsmi-ijgb.com/
PTAC (2009). Retrieved Jul. 03, 2014, from http://www.ptac.gov.lv/page/104

Riga Internationl airport (2009). Retrieved Jun. 15, 2014, from http://www.riga-airport.com/lv/main/sakumlapa

Riga Technical University (2013). Retrieved Jun. 15, 2014, from http://www.rtu.lv/

Rīgas siltums (2014). Retrieved Jun. 15, 2014, from http://www.rs.lv/

Road Traffic Safety Directorate of the Republic of Latvia. (2011). Retrieved Jun. 15, 2014, from http://www.csdd.lv/

Sheahan, P. (2006). Generation Y. Prahran: Hardie Grant Publishing.

SIVA (2006-2012). Retrieved Jul. 03, 2014, from http://www.siva.gov.lv/aktualitates.html

Starineca, O. (2014). Generation Y Potential Employees - A Public Sector Stakeholder. The 72nd conference of the University of Latvia, February 3, Riga, Latvia.

Starineca, O., \& Voronchuk, I. (2014). Employer Branding Training Development for Public Organisations. Regional Formation and $\begin{array}{lllll}\text { Development } \quad \text { Studies, } & 3 & \text { (14), } & \text { 207-219. }\end{array}$ http://dx.doi.org/10.15181/rfds.v14i3.877

Sustainability Index (2010-2014). Retrieved Mar. 03, 2014, from http://www.ilgtspejasindekss.lv/

Tukuma novada sociālais dienests (2014). Retrieved Jul. 03, 2014, from http://www.tnsd.lv/

Uzṇēmumu reg̣istrs (2014). Retrieved Jul. 03, 2014, from http://www.ur.gov.lv/

VAAD (2009). Retrieved Jul. 03, 2014, from http://www.vaad.gov.lv/

Valsts dzelzceḷa tehniskā inspekcija (2007). Retrieved Jul. 03, 2014, from http://www.vdzti.gov.lv/

Valsts kase (2007-2014). Retrieved Jul. 03, 2014, from http://www.kase.gov.lv/

Valsts tehniskās uzraudzības aǵentūra (2005-2013). Retrieved Jul. 03, 2014, from http://www.vtua.gov.lv/

VARAM (2006). Retrieved Jul. 03, 2014, from http://www.varam.gov.lv/

Ventspils reiss (2014). Retrieved Jun. 15, 2014, from http://www.ventspilsreiss.lv/

VID (2005). Retrieved Jul. 03, 2014, from https://www.vid.gov.lv/

Vides pārraudzības valsts birojs (2009). Retrieved Jul. 03, 2014, from http://www.vpvb.gov.lv/lv

Voronchuk, I., \& Starineca, O. (2014). Human Resource Recruitment and Selection Approaches in Public Sector: Case of Latvia. International Scientific Conference "New Challenges of Economic and Business Development - 2014" Proceedings, 2014, 417-430. Retrieved from Ekonomikas un vadības fakultāte. Retrieved from http://www.evf.lu.lv

Voronchuk, I., \& Starineca, O. (2014). Social Responsibility Initiative Implementation in Public Sector in Latvia. 3rd International Scientific-Practical Conference Good Governance At Local SelfGovernment: Involvement, Collaboration And Empowerment For Regional Development, October 17-18, Šiauliai, Lithuania.

Voronchuk, I., \& Starineca, O. (2014a). Socially Responsible Organisations' Training on Employer Brand Creation. The 22nd annual NISPAcee Conference. May 22-24, Budapest, Hungary.

VRAA (2014). Retrieved Jul. 03, 2014, from http://www.vraa.gov.lv/lv/

VSAA (2014). Retrieved Jul. 03, 2014, from http://www.vsaa.lv/

VZD (2014). Retrieved Jul. 03, 2014, from http://www.vzd.gov.lv/lv/

Zemkopības ministrija (2011). Retrieved Jul. 03, 2014, from http://www.vmd.gov.lv/\#jump

Zemkopības ministrija (2011). Retrieved Jul. 03, 2014, from https://www.zm.gov.lv/

Olga Starineca received the Bachelor (B. sc. oec.) degree in Management in 2011 and the Master degree in Management (MSM) in 2013 from Riga Technical University, Latvia. She is currently continuing her studies at the University of Latvia to gain the degree of Doctor of Social Sciences (Dr. sc. administr.) in Management.

From March till August 2012 she took an internship with the European Commission, Department of HR and Security, conducting the research on ethics issues in the public sector. Currently she is a Mentor and Sales Trainer at the Riga chapter of AIESEC Latvia. She has worked as a Senior Teacher Assistant at Stockholm School of Economics in Riga on an HRM course for bachelor students since August 2013

Her research interests lay in human resources management, public administration and social responsibility issues.

She is a member of the Regional Studies Association.

E-mail: Olga.Starineca@rtu.lv 